\title{
Research on Undertaking Ability of China's Processing Trade Industries
}

$$
\text { Xin-Ying LIU }{ }^{1, a,{ }^{*}} \text {, Wen-Wen LIU }{ }^{2, b}
$$

${ }^{1,2}$ College of International Economics and Trade, Shandong University of Finance \& Economics,

\author{
Jinan, Shandong, China, 250014 \\ asheila_guo1988@hotmail.com, bliuwenwen888999@163.com \\ ${ }^{*}$ Corresponding author
}

Keywords: Industrial gradient transfer, Industrial gradient coefficient, Principal component analysis.

\begin{abstract}
Enterprises in central and western regions undertake industries from eastern region enterprises according to their own advantage, which would promote their own economic development and narrow the economic development gap between eastern region, central region and western region. By analyzing the factors affecting enterprises' undertaking ability in central and western regions using principal component analysis, undertaking regions' undertaking ability can be obtained which can provide some reference for the national industry planning.
\end{abstract}

\section{Introduction}

In the process of reform and opening up, China's coastal areas have developed into processing trade industrial agglomeration area with preferential policies, abundant and cheap labor, land resources and location advantage of waterfront. Processing trade industries mainly concentrate in traditional industries, and, after years of development, they have formed a large scale of economy and their own brand.

But along with the rapid development of economy in eastern regions, some problems have emerged. Problems like insufficient resources, the rise of land prices and labor shortages, have hindered the further development of industry. There are a lot of high energy consumption and low value added industries in eastern region which influence the overall development of the regional economy. By transferring backward industries, the enterprises in eastern region can develop high-end sectors and optimize the industrial structure. In addition, the low labor cost competition from surrounding countries also makes the profit of processing trade industry in eastern region becomes less and less. Part of the processing trade industries transfer away from the eastern regions can reduce the cost and expand the enterprise's profit space.

From the perspective of transfer industry, the transfer mainly concentrates on labor-intensive industries and resource intensive industries. Labor intensive industry depends on low cost labor, but owing to the rising cost of labor many labor-intensive industries in eastern regions choose to transfer to central and Western regions with relatively low labor cost. Compared with the eastern regions, the central and western regions are rich in natural resources, which have great attraction for resource dependent industries.

The labor-intensive industries undertaken by the central and western regions can greatly promote employment opportunities. Furthermore, a portion of talents of the first gradient areas with advanced business philosophy, advanced management experience are introduced which improves the overall quality of labor force in the central and western regions.

Capital investment from industry transfer region can make up for the funds shortfall, which provides some support for the stable economic growth of industry undertaking region. There are technology spillover effects during the industrial transfer process of eastern region. By leveraging cost advantage, combined with advanced technology, the enterprises in industry undertaking regions can achieve long-term development.

${ }^{1}$ Xinyiing Liu: Dr. and Prof. of Shandong University of Finance and Economics, majored at English and International Economics with bachelor degree of English and master as well as $\mathrm{PhD}$ degree in economics, the tutor of masters in International Trade.

${ }^{2}$ Wenwen Liu: PhD. candidate of Shandong University of Finance and Economics, majoring in International Economics. 
There are some energy-intensity enterprises and heavy pollution enterprises in eastern region. Owing to resource scarcity and strict environmental legislation, these enterprises have to move out in order to survive. In order to promote economic growth, the central and western regions introduced many enterprises which can increase revenue but also pollute environment seriously. These industries would hurt the local environment, and the economic development of the central and western regions would fall into a vicious cycle.

\section{Literature Reviews about Industrial Gradient Transferring and Principal Component Analysis}

Vernon L. Smith brought forward the product life cycle theory in 1960s, later the further development by Wells and Hirsh in the second half of the twentieth century. The theory formed gradient transfer theory of regional economic development gradually. According to this theory, a region's economic gradient depends on the region's industrial strength, and the industry transfer trend is from high gradient regions to low gradient regions.

In the early 1980s, the gradient transfer theory was introduced into China (Xia Yunong, He Zhongxiu, 1982; Liu Guoguang, 1983) and many domestic scholars studied at it. Chen Gang, Chen Honger (2001) studied regional industrial transfer's influence on both industrial transfer regions and industrial undertaking regions. Dai Hongwei, Tian Xuebin and Chen Yongguo (2003) measured the industrial gradient coefficient using location quotient and comparative labor productivity. Chen Rui, Xiong Bilin (2007) analyzed the key factors affecting the industrial transfer, and industrial transfer's implementation mechanism under the influence of government and the market rules tested by a modified industrial gradient coefficient method. Ma Tao, Li Dong, et al. (2009) evaluated the industrial undertaking ability of all regions in China from the perspective of industrial division. An Zengjun, Yang Min (2013) constructed an analytic hierarchy process model of evaluating cross strait industrial transfer effect, and put forward the suggestions of cross-strait industrial transfer direction and mode on the basis of empirical results.

\section{Research on Industrial Undertaking Ability of China's Central and Western Regions}

We can get which factors influence industrial undertaking ability of a region and the industrial undertaking capacity situation of the second and third gradient regions by principal component analysis. So the industrial undertaking regions can pay attention to the factors affecting industrial undertaking effect, and the analysis results can provide some references for the selection of key industrial undertaking regions.

\section{The Selection of Index and Data Source}

Industrial Gradient Coefficient. A country or a region's industrial gradient situation is related to its industrial structure, factor endowments and technological level closely. Industrial gradient is the premise of industrial transfer, and the economic development differences between regions are the objective basis of industrial transfer. Industrial gradient coefficient can be calculated in accordance to the following formulae.

The comparative labor productivity=the ratio of regional industrial output value to national industrial output value/ the ratio of region industrial practitioners to national industrial practitioners.

Location quotient=the ratio of regional industrial output value to gross regional product / the ratio of national industrial output value to gross domestic product.

Industrial gradient coefficient=location quotient $\times$ the comparative labor productivity

Principal Component Analysis. In order to fully reflect the industrial undertaking ability situation of central region and western region, four first grade indexes and eleven second grade indexes are selected. The eleven indexes are: $\mathrm{R} \& \mathrm{D}$ personnel ratio $\left(X_{1}\right), \mathrm{R} \& \mathrm{D}$ expenditure ratio $\left(X_{2}\right)$, R\&D projects ratio $\left(X_{3}\right)$, Length of Railways in Operation $\left(X_{4}\right)$, Total Length of Highways $\left(X_{5}\right)$,Freight traffic $\left(X_{6}\right)$, Ratio of Total Assets to Industrial Output Value $\left(X_{7}\right)$, Ratio of 
Profits to Industrial $\operatorname{Cost}\left(X_{8}\right)$, Proportion of Products Sold $\left(X_{9}\right)$, Energy Consumption per Unit of GDP/GRP $\left(X_{10}\right)$, Electricity Consumption per Unit of GDP/GRP $\left(X_{11}\right)$. Indexes data comes from China statistical yearbook on science and technology, China Statistical Yearbook and Provincial Statistical Yearbook yearly.

TABLE 1 INDUSTRIAL UNDERTAING ABILITY INDES

\begin{tabular}{|c|c|c|}
\hline $\begin{array}{l}\text { First grade } \\
\text { index }\end{array}$ & $\begin{array}{l}\text { Second grade } \\
\text { index }\end{array}$ & Index explanation \\
\hline \multirow[t]{3}{*}{$\begin{array}{l}\text { Technolog } \\
\text { ical Index }\end{array}$} & $\begin{array}{l}\text { R\&D } \\
\text { personnel ratio }\end{array}$ & $\begin{array}{l}\text { R\&D personnel refer to the personnel involved in research and } \\
\text { experimental development research, management and } \\
\text { support work which is an internationally comparable indicator of } \\
\text { S\&T manpower input. R \& D personnel ratio is regional R \& } \\
\text { D personnel accounted in national R \& D personnel. }\end{array}$ \\
\hline & \begin{tabular}{|c|}
\multicolumn{2}{|c|}{$\mathrm{R} \& \mathrm{D}$} \\
expenditure ratio
\end{tabular} & $\begin{array}{l}\mathrm{R} \& \mathrm{D} \text { expenditure ratio is regional } \mathrm{R} \& \mathrm{D} \\
\text { expenditure ratio accounted in national } \mathrm{R} \& \mathrm{D} \text { expenditure ratio. }\end{array}$ \\
\hline & $\begin{array}{c}\mathrm{R} \& \mathrm{D} \\
\text { projects ratio }\end{array}$ & $\begin{array}{l}\mathrm{R} \& \mathrm{D} \text { projects ratio is regional } \mathrm{R} \& \mathrm{D} \text { projects ratio accounted } \\
\text { in national } \mathrm{R} \& \mathrm{D} \text { projects ratio. }\end{array}$ \\
\hline \multirow[t]{3}{*}{$\begin{array}{l}\text { Logistics } \\
\text { Index }\end{array}$} & $\begin{array}{l}\text { Length of } \\
\text { Railways in } \\
\text { Operation }\end{array}$ & $\begin{array}{l}\text { Length of railways in operation refers to the total length of the } \\
\text { trunk line under passenger and freight transportation (including } \\
\text { both full operation and temporary operation). The length of } \\
\text { railways in operation is an important indicator to show the } \\
\text { development of the infrastructure for the railway transport, and } \\
\text { also the essential data to calculate volume of passenger freight } \\
\text { transport, traffic density and utilization efficiency of the } \\
\text { locomotives and carriages. }\end{array}$ \\
\hline & $\begin{array}{l}\text { Total Length of } \\
\text { Highways }\end{array}$ & $\begin{array}{l}\text { Total length of highways refers to the length of highways which } \\
\text { are built in conformity with the grades specified by the highway } \\
\text { engineering standard formulated by the Ministry of } \\
\text { Communications, and have been formally checked and } \\
\text { accepted by the departments of highways and put into use. The } \\
\text { length of highways is an important indicator to show the } \\
\text { development of the highway construction and to provide essential } \\
\text { information to calculate the transport network density. }\end{array}$ \\
\hline & Freight traffic & $\begin{array}{l}\text { Freight traffic refers to the volume of freight transported with } \\
\text { various means. The freight traffic provides a quantitative measure } \\
\text { to show how the transport industry serves the national economy } \\
\text { and people, and is also an important indicator for planning the } \\
\text { transport industry and for studying the development scale and } \\
\text { speed of the transport industry. }\end{array}$ \\
\hline \multirow[t]{3}{*}{$\begin{array}{l}\text { Capital } \\
\text { Efficiency } \\
\text { Index }\end{array}$} & $\begin{array}{l}\text { Ratio of Total } \\
\text { Assets to } \\
\text { Industrial Output } \\
\text { Value (\%) }\end{array}$ & $\begin{array}{l}\text { Ratio of total assets to industrial output value reflects the } \\
\text { profit-making capability of all assets of the enterprise and is a key } \\
\text { indicator manifesting the performance and management and } \\
\text { evaluating the profit-making potential of the enterprise. }\end{array}$ \\
\hline & $\begin{array}{c}\text { Ratio of Profits to } \\
\text { Industrial Cost }\end{array}$ & $\begin{array}{l}\text { Ratio of profits to industrial cost refers to the ratio of profits } \\
\text { realized in a given period to the total costs in the same period, } \\
\text { which reflects the economic efficiency of input cost. }\end{array}$ \\
\hline & $\begin{array}{l}\text { Proportion of } \\
\text { Products Sold }\end{array}$ & $\begin{array}{l}\text { Proportion of products sold refers to the ratio of total sales in a } \\
\text { given period to the gross output value in the same period, which } \\
\text { reflects the extent of industrial output sold. }\end{array}$ \\
\hline \multirow[t]{2}{*}{$\begin{array}{l}\text { Energy } \\
\text { Index }\end{array}$} & $\begin{array}{l}\text { Energy } \\
\text { Consumption } \\
\text { per Unit of } \\
\text { GDP/GRP }\end{array}$ & $\begin{array}{l}\text { Energy consumption per unit of GDP/GRP refers to the energy } \\
\text { consumption per unit of gross domestic product in a country or the } \\
\text { gross regional product in a region in the same reference period. }\end{array}$ \\
\hline & $\begin{array}{l}\text { Electricity } \\
\text { Consumption } \\
\text { per Unit of } \\
\text { GDP/GRP }\end{array}$ & $\begin{array}{l}\text { Electricity consumption per unit of GDP/GRP refers to the } \\
\text { electricity consumption per unit of gross domestic product in a } \\
\text { country or the gross regional product in a region in the same } \\
\text { reference period. }\end{array}$ \\
\hline
\end{tabular}




\section{Empirical Analysis}

\section{Industrial Gradient Coefficient}

Thirty-one provinces, municipalities and autonomous regions of China are divided into three gradients by analyzing China's processing trade industrial conditions which is identical with the eastern region, the central region and western region geographical. Among them, the first gradient includes ten provinces, the second gradient includes fourteen provinces, and the third gradient includes seven provinces and cities.

TABLE 2 CHINA'S PROCESSING TRADE INDUSTRIAL GRADIENT SITUATIONS OF 2012

\begin{tabular}{|c|c|c|c|c|c|}
\hline \multicolumn{2}{|c|}{ The first gradient } & \multicolumn{2}{c|}{ The second gradient } & \multicolumn{2}{c|}{ The third gradient } \\
\hline Province & $\begin{array}{c}\text { Industrial } \\
\text { gradient coefficient }\end{array}$ & Province & $\begin{array}{c}\text { Industrial } \\
\text { gradient coefficient }\end{array}$ & Province & $\begin{array}{c}\text { Industrial } \\
\text { gradient coefficient }\end{array}$ \\
\hline Liaoning & 1.1371 & Guangdong & 0.6196 & Hebei & 0.0190 \\
\hline Gansu & 1.5301 & Yunnan & 0.9656 & Shanxi & 0.0352 \\
\hline Anhui & 1.2652 & Heilongjiang & 0.7998 & Tibet & 0.0596 \\
\hline Hubei & 1.4213 & Sichuan & 0.8027 & Henan & 0.0851 \\
\hline Tianjin & 1.8489 & Shaanxi & 0.8867 & Beijing & 0.2649 \\
\hline Jilin & 1.6698 & Fujian & 0.9654 & Guizhou & 0.5208 \\
\hline Jiangxi & 1.7061 & Hainan & 0.9784 & Chongqing & 0.5223 \\
\hline Jiangsu & 1.7266 & Qinghai & 0.9832 & & \\
\hline Shandong & 2.7701 & Shanghai & 1.0187 & & \\
\hline Zhejiang & 2.9424 & Xinjiang & 1.0196 & & \\
\hline & & Hunan & 1.0291 & & \\
\hline & & Ningxia & 1.0630 & & \\
\hline & & Guangxi & 1.0880 & & \\
\hline & & $\begin{array}{c}\text { Inner } \\
\text { Mongolia }\end{array}$ & 1.1183 & & \\
\hline
\end{tabular}

\section{Principal Component Analysis}

Indexes are divided into four groups, among which, $X_{1}$ to $X_{3}$ represents science and technology, $X_{4}$ to $X_{6}$ represents logistics situation, $X_{7}$ to $X_{9}$ represents capital cases, $X_{10}$ and $X_{11}$ represents energy situation.

When analyze problems with principal component analysis, there is a problem of direction and magnitude's different between indexes. In order to achieve comparability between indexes, the first step is normalizing the data.

The principal components can be extracted when there is correlation between indexes. KMO statistics and Bartlett's test can test whether the indexes are suitable for principal component analysis, and the indexes pass the test.

Four principal components can be extracted from the four group indexes according to the characteristic roots situation, which means the four principal components would represent the data information of the original eleven indexes.

The principal component formula can be obtained after calculating the data of initial factor loading matrix. Comprehensive principal component formula can be obtained weight according to the weights of the four principal components.

$$
\begin{aligned}
& F_{2007}=0.97033 F_{1}+0.72579 F_{2}+0.76445 F_{3}+0.95325 F_{4} \\
& F_{2008}=0.94531 F_{1}+0.70655 F_{2}+0.81609 F_{3}+0.95081 F_{4} \\
& F_{2009}=0.98804 F_{1}+0.73977 F_{2}+0.94868 F_{3}+Z X \\
& F_{2010}=0.99139 F_{1}+0.73137 F_{2}+0.94522 F_{3}+Z X \\
& F_{2011}=0.98841 F_{1}+0.72689 F_{2}+0.91765 F_{3}+Z X \\
& F_{2012}=0.98977 F_{1}+0.74235 F_{2}+0.84941 F_{3}+Z X
\end{aligned}
$$


We can get the industrial undertaking ability situation of the second and third gradient from 2007 to 2012 by calculating.

TABLE 3 THE INDUSTRIAL UNDERTAKING ABILITY SITUATION OF THE SECOND AND THIRD GRADIENT

\begin{tabular}{|c|c|c|c|c|c|c|c|c|c|c|c|c|}
\hline & \multicolumn{2}{|c|}{2007} & \multicolumn{2}{|c|}{2008} & \multicolumn{2}{|c|}{2009} & \multicolumn{2}{|c|}{2010} & \multicolumn{2}{|c|}{2011} & \multicolumn{2}{|c|}{2012} \\
\hline & \multicolumn{6}{|c|}{ ScoreRanking } & \multicolumn{6}{|c|}{ ScoreRankingScoreRankingScoreRanking } \\
\hline Beijing & 6.19 & 1 & -2.99 & 19 & -3.99 & 20 & -4.35 & 20 & -4.22 & 20 & -4.07 & 20 \\
\hline Fujian & 1.30 & 7 & 1.14 & 7 & 1.36 & 5 & 1.34 & 5 & 1.40 & 5 & 1.47 & 6 \\
\hline Guangdong & -0.92 & 15 & 1.23 & 5 & 0.27 & 8 & 0.32 & 8 & 0.20 & 8 & -0.21 & 11 \\
\hline Guangxi & 0.21 & 12 & 1.40 & 4 & 1.98 & 4 & 2.17 & 4 & 1.98 & 4 & 1.75 & 4 \\
\hline Guizhou & 3.12 & 2 & 3.02 & 2 & 0.9 & 7 & 1.23 & 6 & 1.26 & 6 & 1.09 & 7 \\
\hline Hainan & 1.07 & 9 & $\mid-1.72$ & 17 & -1.35 & 17 & -1.36 & 17 & -1.25 & 17 & -1.65 & 16 \\
\hline Hebei & $\mid-0.18$ & 13 & $\mid-1.62$ & 15 & -0.92 & 15 & -0.85 & 16 & -0.50 & 13 & -0.22 & 12 \\
\hline Henan & 2.95 & 3 & 2.93 & 3 & 4.24 & 2 & 3.71 & 2 & 3.51 & 2 & 3.12 & 2 \\
\hline Heilongjiang & 1.79 & 6 & 0.57 & 10 & 2.08 & 3 & 2.35 & 3 & 2.52 & 3 & 2.49 & 3 \\
\hline Hunan & 2.12 & 4 & 5.69 & 1 & 7.08 & 1 & 6.99 & 1 & 6.53 & 1 & 6.86 & 1 \\
\hline nner Mongolia & a-0.72 & 14 & -2.20 & 18 & -1.34 & 16 & -0.82 & 15 & -1.03 & 16 & -0.63 & 15 \\
\hline Ningxia & -1.04 & 16 & $\mid-4.00$ & 20 & -2.45 & 19 & -3.00 & 19 & -2.94 & 19 & -3.06 & 19 \\
\hline Qinghai & -1.15 & 17 & -1.66 & 16 & -1.54 & 18 & -1.72 & 18 & -1.78 & 18 & -2.13 & 18 \\
\hline Shanxi & 1.82 & 5 & 0.81 & 9 & 1.22 & 6 & 0.70 & 7 & 0.83 & 7 & 1.51 & 5 \\
\hline Shaanxi & -3.32 & 18 & -0.31 & 13 & -0.5 & 13 & -0.12 & 10 & -0.38 & 12 & 0.48 & 8 \\
\hline Shanghai & 0.75 & 11 & $\mid-0.74$ & 14 & -0.31 & 12 & -0.43 & 14 & -0.50 & 14 & -0.28 & 13 \\
\hline Sichuan & -3.97 & 19 & -4.13 & 21 & -5.65 & 21 & -5.62 & 21 & -5.18 & 21 & $\mid-5.01$ & 21 \\
\hline Tibet & 1.29 & 8 & 0.35 & 11 & -0.12 & 10 & 0.07 & 9 & 0.09 & 10 & 0.45 & 9 \\
\hline Xinjiang & -4.83 & 20 & 1.17 & 6 & -0.78 & 14 & -0.15 & 12 & -0.03 & 11 & -0.60 & 14 \\
\hline Yunnan & -7.38 & 21 & 0.03 & 12 & 0.08 & 9 & -0.32 & 13 & -0.70 & 15 & -1.68 & 17 \\
\hline Chongqing & 0.88 & 10 & 1.02 & 8 & -0.26 & 11 & -0.15 & 11 & 0.19 & 9 & 0.31 & 10 \\
\hline
\end{tabular}

In order to observe the industrial undertaking ability situation of the second and third gradient more clearly, we analyze the industrial undertaking ability of the second gradient region and the third gradient region respectively.

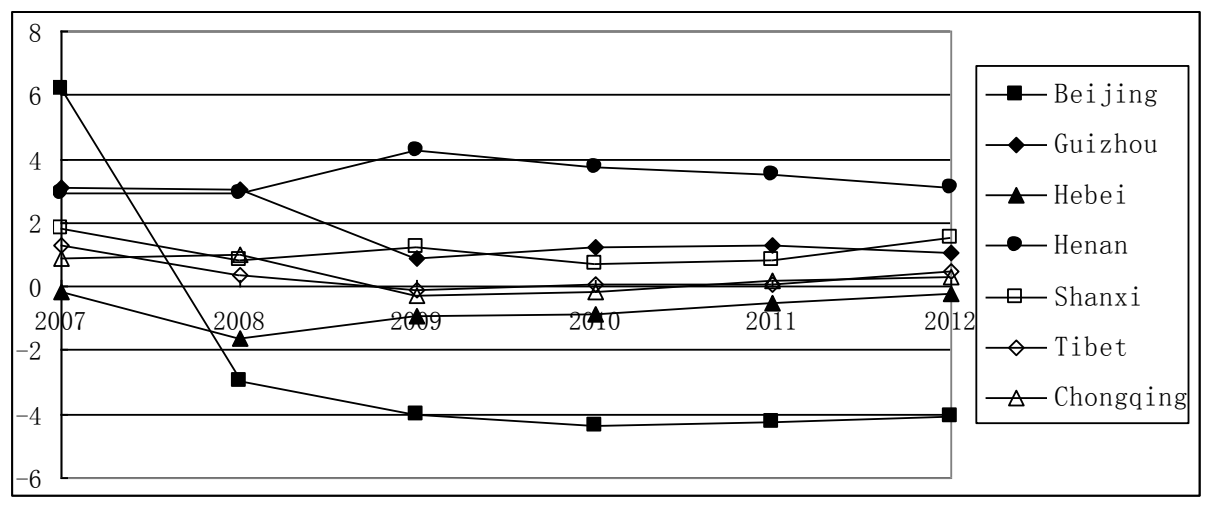

Fig 1. The Industrial Undertaking Ability of the Second Gradient From 2007 to 2012

As it can be seen from Figure 1, the industrial undertaking ability of Beijing, Guizhou, Henan, Chongqing and Tibet appear downward trend. The industrial undertaking ability of Hebei and Shanxi appear downward trend at first then they start showing an upward trend. The industrial undertaking ability of Henan is the strongest among the second gradient region, and the industrial undertaking ability of Beijing is the weakest among the second gradient region.

As it can be seen from Figure 2, the industrial undertaking ability of Hainan, Qinghai and Yunnan appear downward trend. The industrial undertaking ability of Fujian, Guangxi and Hunan appear upward trend. The industrial undertaking ability of Guangdong, Heilongjiang, Inner Mongolia, Ningxia, Shaanxi, Shanghai, Sichuan and Xinjiang show the state of twists and turns. 
The industrial undertaking ability of Hunan is the strongest among the third gradient region, and the industrial undertaking ability of Sichuan is the weakest among the third gradient region.

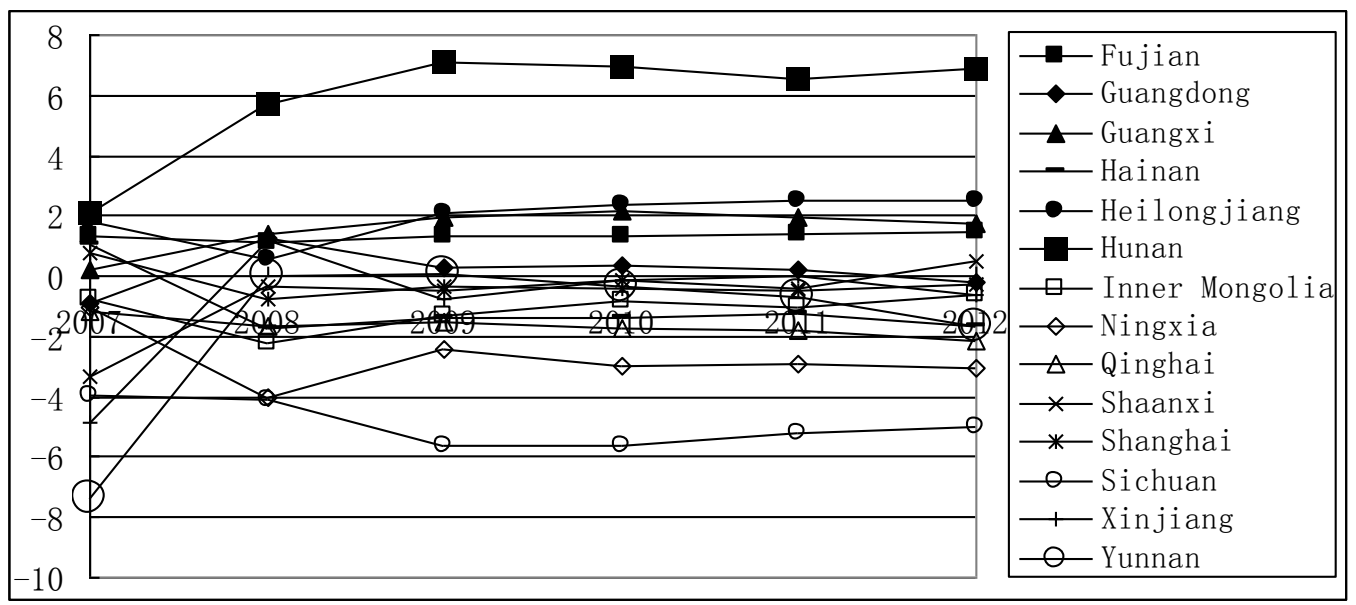

Fig 2. The Industrial Undertaking Ability of the Third Gradient from 2007 to 2012

\section{Proposals on Promoting the Central and Western Regions' Industrial Undertaking \\ Improved Supporting Facilities}

Convenient transportation facilities and efficient communications equipment are beneficial for enterprise's development, so it is necessary further increase infrastructure's investment in central region and western region.

On one hand, increase investment in various transportation lines.

Develop comprehensive transportation network focusing on highway, railroad and shipping. Reduce logistics costs and increase efficient interoperability between eastern region and central, western region by integrated transport system.

On the other hand, the second gradient region and the third gradient region need to increase investment on communication facilities, such as broadband network, optical fiber communication and mobile communications. Establish information resources sharing platform with the first gradient of region which is helpful for capturing market dynamics sharply. Meanwhile, industrial undertaking information network should be built which can provide advice for industrial transfer enterprises and reduce projects' dispersion and blindness by guiding the transfer industries to industrial agglomeration area.

\section{Strengthened Talent Support}

The gifted talent plays a very important role in the development of an enterprise, especially for the second gradient region and the third gradient region.

On one hand, the second, gradient region and the third gradient region need to attract high-quality personnel. Enterprises can attract talent with preferential recruitment conditions, such as solving family members' job and providing accommodation. And in order to train local personnel learning advanced technology, it is critical to invite outstanding entrepreneurs and professionals as technical instructor.

On the other hand, lay stress on the training of local talents. Increase capital investment on manpower to train the needed talent of enterprises. Enterprises should strengthen the link with universities and research institutes to develop needed human resources. Also, enterprises can sign oriented talent training plan directly with universities directly to culture targeted talent. Enterprises' innovation ability and industrial undertaking ability can be enhanced by improving quality of talent.

\section{Protected Environments}

The central region and western region should manage the relationship between economic development and environmental protection appropriately. We should assessing environmental 
impact of the transfer projects, and limit the high pollution transfer industry effectively. It is necessary to pay more attention to the undertaking industry's scientific and technological content along with introducing the high-technology and less-pollution industry emphatically.

We should also emphasize enterprises' energy conservation. Enhance the enterprises' overall competitiveness and sustainable development by realizing low consumption, low emission and high efficiency during production process. To develop energy saving and emission reduction technology will be another ways and to provide technical guarantee for industrial undertaking by means of pollution prevention and control technology as well as ecological protection technology.

\section{Conclusion}

The industrial undertaking ability's analysis of central region and western region can provide references for the selection of industrial undertaking areas. Technological factors, logistical factors and capital efficiency factor play an important role in industrial undertaking ability. Energy factor also has an important influence on industrial undertaking ability. Yunnan, Xinjiang and Shaanxi's energy consumption are the most which appear upward trend, and Beijing's energy consumption is the least which shows downward trend. We should not only focus on improving technology, increasing capital, perfecting supporting facilities, but also lay stress on energy protection. Analyze regional planning of industrial undertaking comprehensively combining with various factors which impact industrial undertaking.

\section{References}

[1] Xia Yunong, He Zhongxiu, Gradient Theory and Propose[J]. Research and Recommendations, 1982(8).

[2] Liu Guoguang, Research on the Development Strategy of Chinese Economy [M]. Shang Hai: Shanghai People's Publishing House, 1984(1).

[3] Lu Genxin. Research on International Industrial Transfer [M]. Shang Hai: Shanghai People's Publishing House, 1997.

[4] Chen Gang, Chen Honger. Research on Regional Industrial Transfer Theory [J]. Guizhou Social Sciences, 2001(4).

[5] Dai Hongwei, Tian Xuebin, Chen Yongguo. Research on Regional Industrial Transfer-Take the "Beijing" Economic Circle as an Example [M]. Beijing: Chinese Price Press, 2003.

[6] Chen Rui, Xiong Bilin. Chinese Regional Industrial Transfer Strategic Conception Based on Improved Industrial Gradient Coefficient [J]. Forum on Science and Technology in China, 2007(8).

[7] Li Songzhi, Liu Yebiao. Review on Foreign Research of Industrial Transfer [J]. Inquiry into Economic Issues, 2007(2).

[8] Ma Tao, Li Dong, Yang Jianhua, Zhai Xiangru. Evaluation on Regional Division Gap-in the Perspective of Industrial Undertaking Ability [J]. Management World,2009(9).

[9] An Zengjun, Yang Min. Research on the Model Construction and Empirical Study of Cross-strait Industrial Transfer Effect[J].Southeast Academic Research,2013(3).

[10] Yang Min, An Zengjun. Research on the Estimated Principles and Methods of Cross-strait Industrial Transfer Effect [J]. Southeast Academic Research,2012(4).

[11]DUNNJES. A Statistical and Analytical Technique for Regional Analysis [J]. Papers of the Regional Science Association, 1960.

[12] O'Donoghue, Dan and Bill Gleave. A Note on Methods for Measuring Industrial Agglomeration [J]. Regional Studies, 2004, vol. 38, issue 4. 